\title{
Aplikasi Pembelajaran Dasar Anak Retardasi Mental Berbasis Android (Studi Kasus: Sekolah Luar Biasa (SLB) C Karya Ibu Palembang)
}

\author{
Ruliansyah $^{1}$, Irfan Dwi Jaya ${ }^{2}$, Septian Syaputra ${ }^{3}$ \\ ruli@radenfatah.ac.id ${ }^{1}$,irfan_dj@radenfatah.ac.id ${ }^{2}$, SeptianSyaputra29@gmail.com ${ }^{3}$ \\ ${ }^{1}$ Prodi Sistem Informasi, Fakultas Sains dan Teknologi, UIN Raden Fatah Palembang \\ ${ }^{2}$ Prodi Sistem Informasi, Fakultas Sains dan Teknologi, UIN Raden Fatah Palembang \\ ${ }^{3}$ Prodi Sistem Informasi, Fakultas Sains dan Teknologi, UIN Raden Fatah Palembang
}

Diterima: 12 Januari 2017 | Direvisi: 13 Februari 2017 | Disetujui: 27 Februari 2017

(c) 2017 Program Studi Sistem Informasi Fakultas Sains dan Teknologi,

Universitas Islam Negeri Raden Fatah Palembang, Indonesia

\begin{abstract}
Abstrak: Retardasi mental adalah suatu kondisi yang ditandai oleh intelegensi yang rendah yang menyebabkan ketidakmampuan individu untuk belajar dan beradaptasi terhadap tuntutan masyarakat atas kemampuan yang dianggap normal. Anak tidak mampu belajar dan beradaptasi karena intelegensi yang rendah, biasanya IQ di bawah 70. Anak-anak retardasi mental mengalami kesulitan dalam mengikuti proses pendidikan. Adanya beberapa hambatan pada anak retardasi mental tersebut memerlukan variasi cara pembelajaran dan memiliki variasi respon terhadap tugas belajar berupa variasi perilaku belajar. Sistem ini berupaya membantu proses belajar anak retardasi mental sebagai alat untuk mempermudah proses pembelajaran. Pada device Android dapat menampilkan objek - objek dengan lebih nyata serta terdapat suara sebagai pendukung pembelajaran, dengan demikian anak akan lebih tertarik dan mampu berkonsentrasi lebih lama. Dari hasil implementasi dan pengujian hasil kuesioner, didapat kesimpulan bahwa melalui Sistem pembelajaran ini telah membantu anak retardasi mental lebih mudah menerima pelajaran dengan mengenal berbagai materi yang disediakan, dengan menyediakan pembelajaran mengenai gambar dan suara.
\end{abstract}

Kata Kunci: Android, Pembelajaran Mobile, Retardasi Mental

\begin{abstract}
Mental retardation is a condition characterized by low intelligence which causes the inability of individuals to learn and adapt to the demands of the community for abilities that are considered normal. Children are unable to learn and adapt because of low intelligence, usually IQs below 70. Children with mental retardation experience difficulties in following the education process. The existence of several obstacles in children with mental retardation requires a variety of learning methods and has a variety of responses to learning tasks in the form of variations in learning behavior. This system seeks to help the learning process of mentally retarded children as a tool to facilitate the learning process. On Android devices can display objects - objects with more real and there is sound as a support for learning, thus the child will be more interested and able to concentrate longer. From the results of the implementation and testing, it was concluded that through this learning system it was helpful for mentally retarded children to receive lessons more easily by knowing the various materials provided, by providing learning about images and sounds.
\end{abstract}

Keywords: Android, Mobile Learning, Mental Redartation

\section{PENDAHULUAN}

Sekolah Luar Biasa C merupakan lembaga pendidikan formal bagi anak-anak berkebutuhan khusus atau disebut tuna garahita. Integrasi antar jenjang dalam bentuk Sekolah Luar Biasa C (SLBC) satu atap, yakni satu lembaga penyelenggara mengelola jenjang TKLBC, SDLBC, SMPLBC dan SMALBC. Sebagai lembaga pendidikan, Sekolah Luar Biasa dibentuk oleh banyak unsur yang diarahkan untuk mencapai tujuan pendidikan, bagi anak- 
anak retardasi mental. Retardasi mental adalah suatu kondisi yang ditandai oleh intelegensi yang rendah yang menyebabkan ketidakmampuan individu untuk belajar dan beradaptasi terhadap tuntunan masyarakat atas kemampuan yang dianggap normal (Soetjiningsih, 2009).

Sekolah Dasar Luar Biasa C Karya Ibu Palembang salah satu lembaga pendidikan bagi anak berkebutuhan khusus dari sekian banyaknya yang ada di Palembang. Sekolah ini memiliki siswa-siswa Tunagrahita yang perkembangan intelektual dan kemampuan adaptif-nya berbeda pada anak normal pada umumnya. Hambatan utama bagi Guru dalam memberikan pelajaran pada anak redaktasi mental adalah keterbatasan anak dalam fungsi mental (fungsi intelektual), dan hambatan dalam beberapa keterampilan perilaku adaptif, seperti berkomunikasi, mengurus dirinya sendiri dan keterampilan sosial, sehingga Anak anak redaktasi mental kesulitan mengikuti proses pendidikan dan pembelajaran yang ada di sekolah. Beberapa hambatan pada anak tersebut memerlukan variasi dalam pembelajaran. Sehingga dibutuhkan alat bantu yang dapat membantu proses pembelajaran, dengan membuat aplikasi pembelajaran yang berbasis mobile application, yaitu aplikasi perangkat lunak yang dibuat khusus dijalankan di dalam tablet dan juga smartphone (Irwansyah \& Moniaga, 2014). Dengan aplikasi yang berbasis mobile application diharapkan mampu membantu pihak sekolah dalam proses pembelajaran.

\section{METODOLOGI PENELITIAN}

\subsection{Metode Pengumpulan Data}

1. Observasi

Observasi merupakan salah satu teknik yang dapat digunakan untuk mengetahui atau menyelidiki tingkah laku nonverbal. Observasi dengan melakukan pengamatan langsung terhadap proses yang sedang berjalan di Sekolah Luar Biasa C Karya Ibu Palembang untuk memperoleh informasi yang nantinya akan diolah kedalam sistem informasi

2. Wawancara

Wawancara merupakan salah satu teknik yang dapat digunakan untuk mengumpulkan data penelitian. Secara sederhana dapat dikatakan bahwa wawancara (interview) adalah suatu kejadian atau proses interaksi antara pewawancara (interviewer) dan sumber informasi atau orang yang diwawancarai (interviewe) melalui komunikasi langsung. Wawancara dilakukan dengan Kepala Sekolah, Guru dan Staff SLB C Karya Ibu dan menghasilkan berupa data sekolah, guru, siswa dan sistem pembelajaran di sekolah tersebut.

3. Dokumentasi

Dokumentasi merupakan catatan seseorang tentang suatu yang sudah berlalu. Dokumen itu dapat berupa bentuk teks tertulis, artefacts, gambar, maupun foto. Dokumentasi yang dilakukan dengan mengamati dokumen yang berada di Sekolah Luar Biasa Karya Ibu Palembang.

\subsection{Metode Pengembangan Sistem}

Metode yang digunakan pengembangan sistem ini adalah Prototype model yaitu metode pengembangan perangkat lunak yang memungkinkan adanya interaksi antara pengembang sistem dengan pengguna sistem, sehingga dapat mengatasi ketidakserasian antara pengembang dan pengguna (Pressman, 2012).

\subsection{Sistem yang Diusulkan}

Perancangan sistem merupakan awal dari pembuatan sistem yang akan dibuat, dimana dapat dilihat proses-proses apa saja yang nantinya diperlukan dalam pembuatan suatu sistem. 


\subsubsection{Pemodelan Proses}

Model proses menggambarkan proses bisnis-kegiatan yang dilakukan orang. Model proses dikembangkan untuk sistem sekarang dan / atau sistem yang akan datang (Dennis, Wixom, \& Roth, 2012). Ada banyak cara untuk mempresentasikan proses model salah satunya menggunakan DFD (Data Flow Diagram).

Data Flow Diagram (DFD) merupakan model dari sistem untuk menggambarkan pembagian sistem ke modul yang lebih kecil (Ladjamudin, 2013). Berikut rancangan sistem yang diusulkan menggunakan $D F D$.

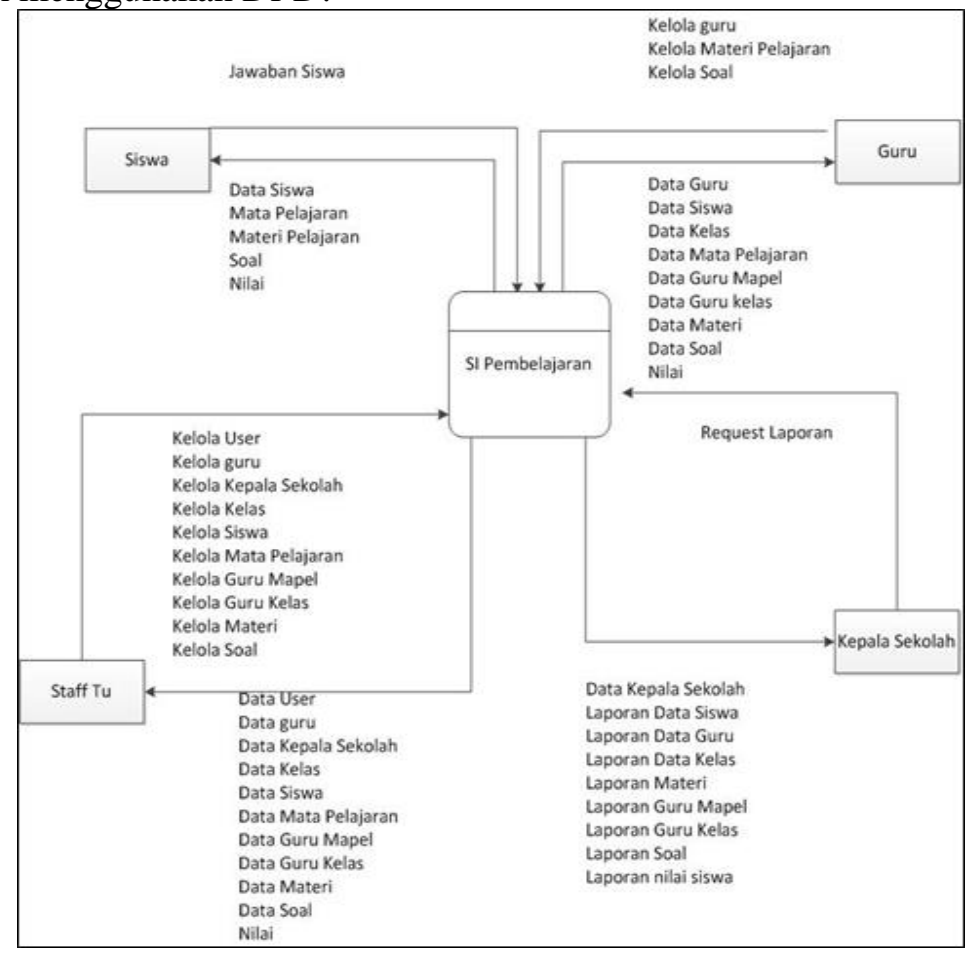

Gambar 1. Diagram Konteks

Pada diagram konteks terdapat empat entitas yang terlibat yaitu Siswa yang dapat mengakses materi pelajaran yang diberikan. Entitas Guru dapat mengelola materi yang terdapat pada aplikasi berdasarkan kebutuhan. Untuk entitas Staff TU mengelola data-data yang dibutuhkan dalam aplikasi, sedangkan entitas Kepala Sekolah dapat memantau dan melihat proses dengan mengakses laporan.

\subsubsection{Pemodelan Data}

Model data menggambarkan aliran data melalui proses bisnis dalam suatu organisasi. Selama fase analisis, model data menyajikan data logis organisasi logis tanpa menunjukkan bagaimana data disimpan (Dennis, Wixom, \& Roth, 2012).

Dalam menggambarkan model data digunakan ERD (Entity Relationship Diagram) yang menunjukkan hubungan antara entitas yang satu dengan yang lain dan juga bentuk hubungannya. Dengan adanya hubungan antar-entitas ini maka seluruh data menjadi tergabung di dalam satu kesatuan yang terintegrasi (Nugroho, 2010). Berikut rancangan model data: 


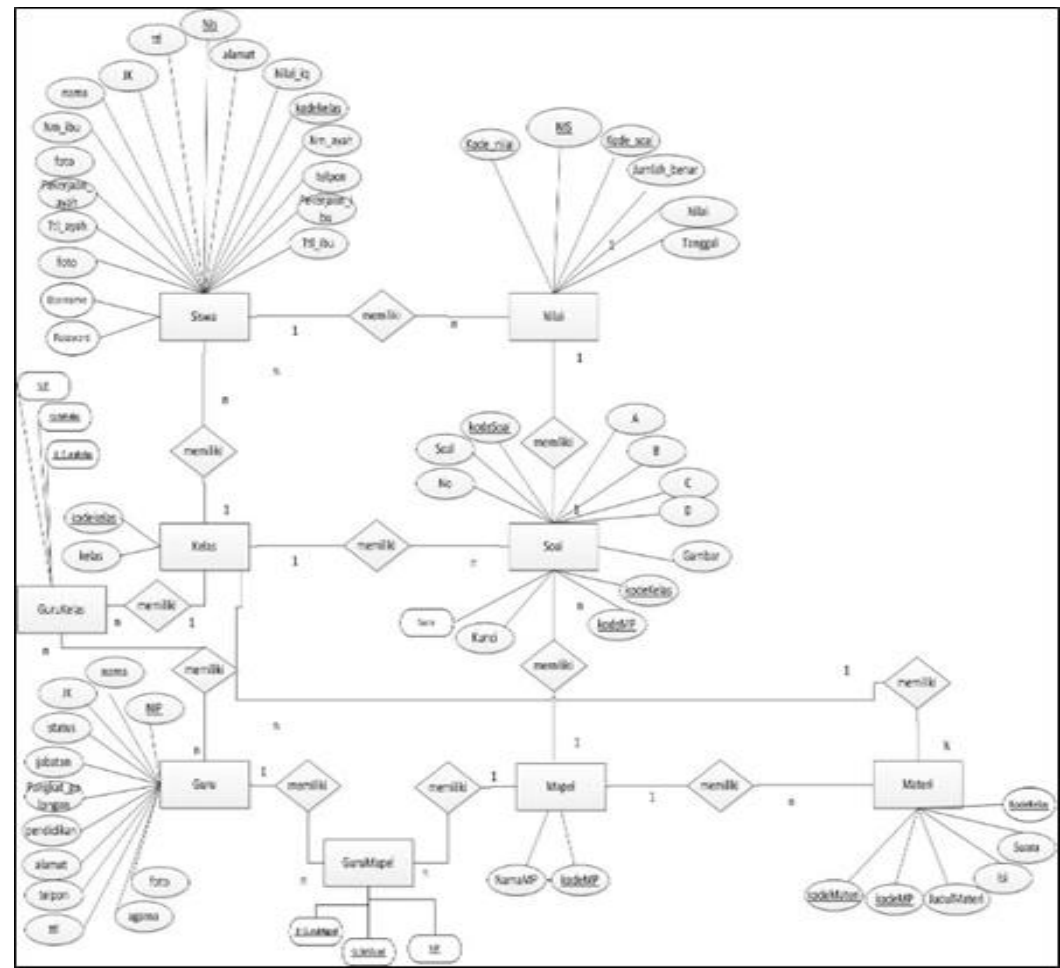

Gambar 2. Diagram $E R D$

\section{HASIL DAN PEMBAHASAN}

Berdasarkan rancangan sistem yang ada, berikut hasil aplikasi yang telah dibuat:

\section{A. Halaman Login}

Halaman login digunakan untuk mengakses aplikasi, berdasarkan username dan password yang sudah diberikan.

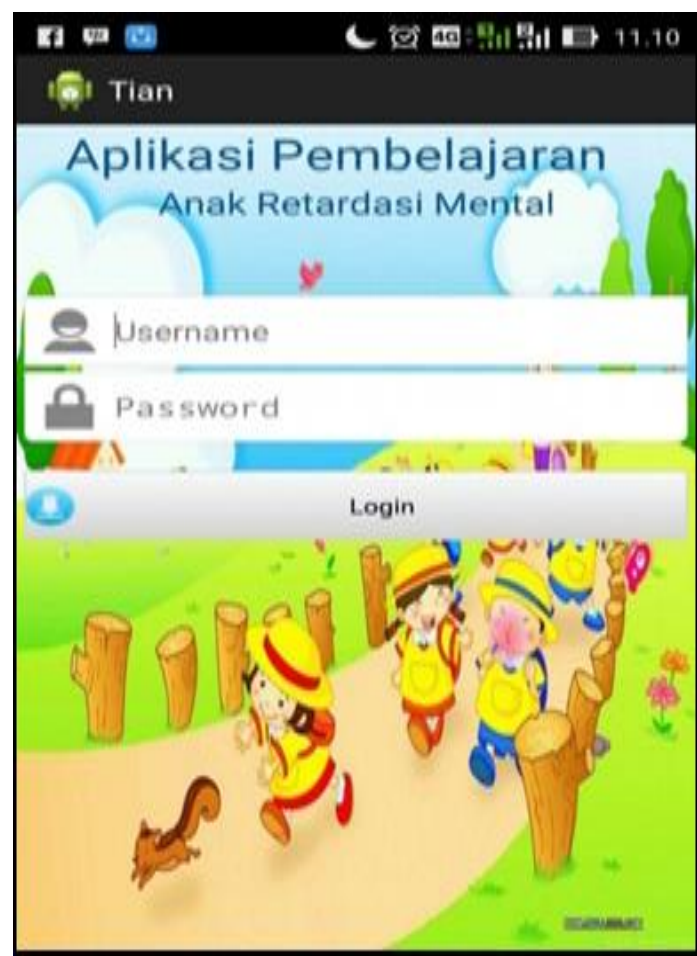

Gambar 3. Halaman Login 


\section{B. Halaman Utama}

Setelah login, maka halaman utama akan ditampilkan yang berisi menu-menu yang akan digunakan dalam proses pembelajaran.

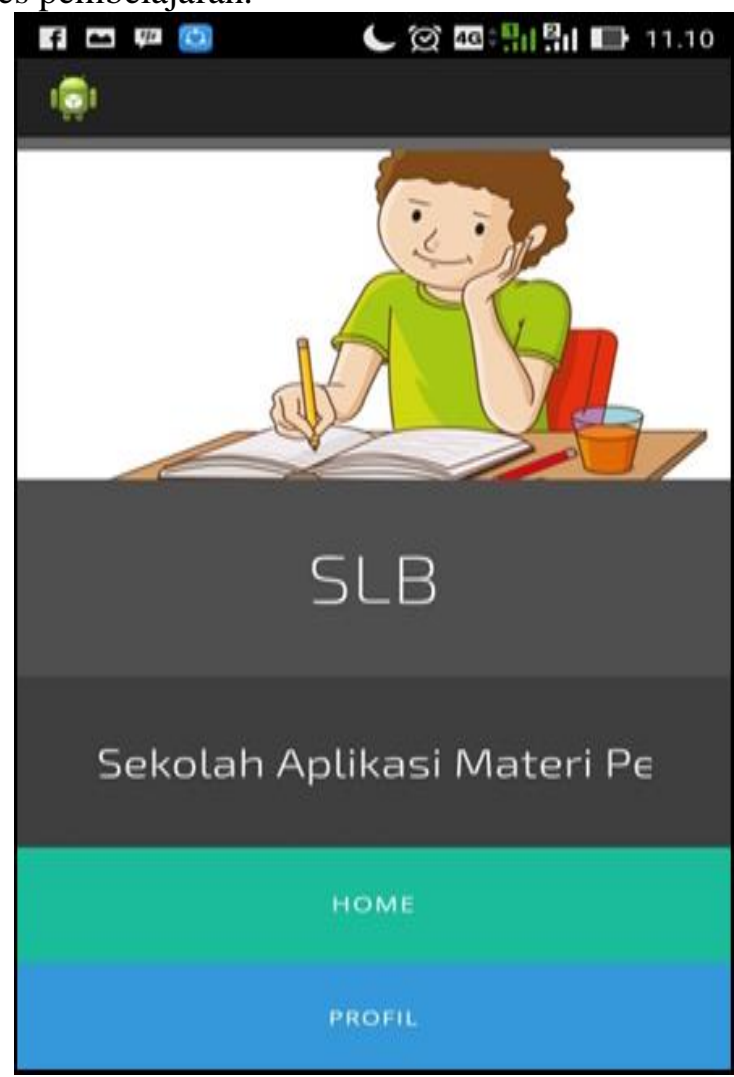

\section{Gambar 4. Halaman Utama}

\section{Halaman Profil Siswa}

Halaman ini digunakan untuk melihat data siswa.

\begin{tabular}{|c|c|}
\hline ․ㅜㅇ $\mathrm{B}$ & 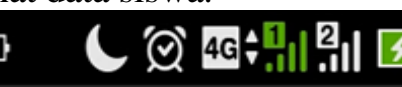 \\
\hline ब्षित & \\
\hline Keterangan & \\
\hline $\mathrm{Nim}$ & 1671051212070005 \\
\hline Nama Siswa & Daffa Aidil Fitransah \\
\hline Jenis Kelamin & $\mathrm{L}$ \\
\hline Kelas & 2 \\
\hline
\end{tabular}

Gambar 5. Halaman Profil Siswa

\section{Halaman Menu Materi dan Soal}

Materi yang dipilih berdasarkan mata pelajaran dimana siswa tersebut terdaftar. 


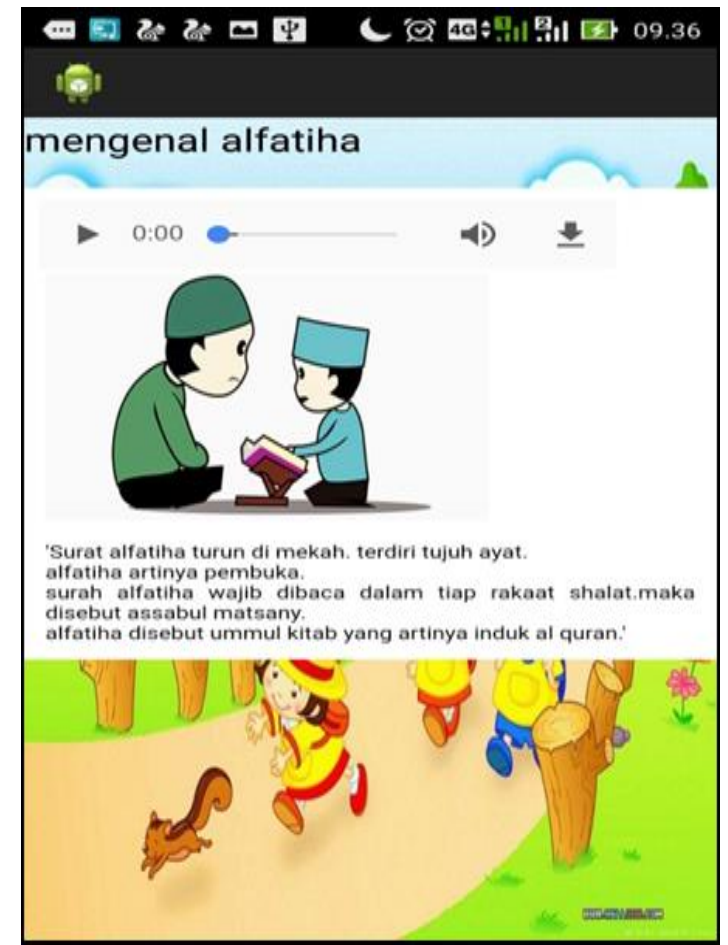

Gambar 6. Halaman Materi

\section{E. Halaman Nilai}

Halaman nilai akan tampil jika siswa telah menjawab soal berdasarkan materi yang dipilih.

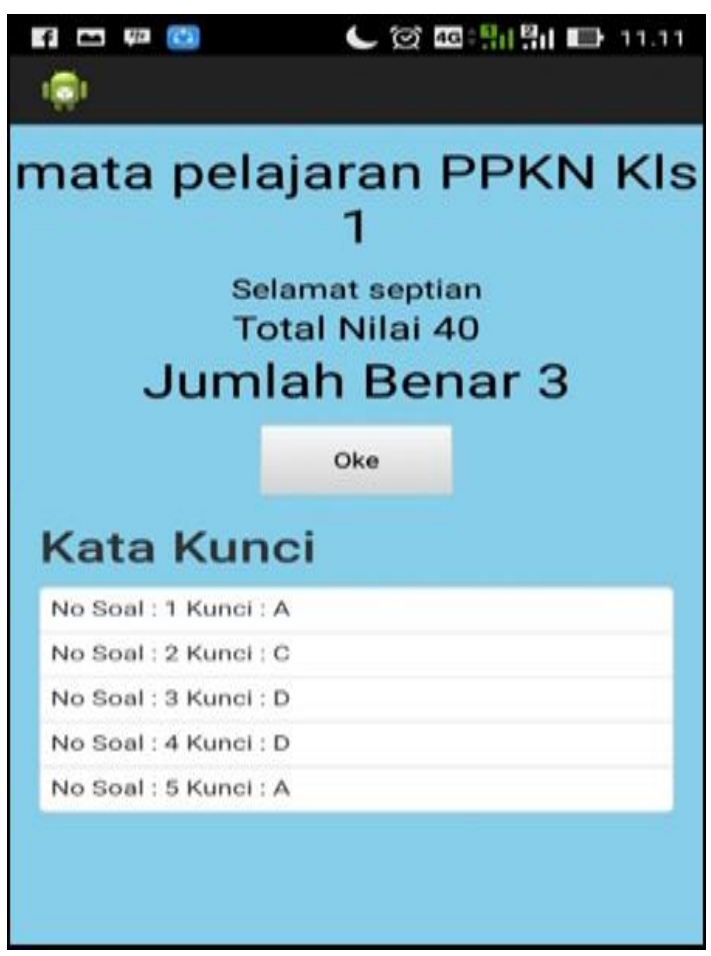

Gambar 7. Halaman Nilai 


\section{F. Halaman Rekapitulasi Nilai}

Halaman rekapitulasi nilai merupakan halaman yang menampilkan keseluruhan nilai yang didapat siswa selama proses pembelajaran.

\begin{tabular}{|l|llllllllll|}
\hline NIS & Nama & \multicolumn{1}{c|}{ Kelas Pancasila OlahRaga IPA IPS MTK Agama Bhs Seni Tot Rata-rata } \\
\hline 1671096006050002 Maya Tahewa 4 & 20 & 40 & 40 & 0 & 80 & 20 & 40 & 40 & 280 & 35 \\
\hline 1671096006050002 Maya Tahewa 4 & 20 & 40 & 20 & 80 & 0 & 40 & 40 & 40 & 280 & 35 \\
\hline 1671096006050002 Maya Tahewa 4 & 20 & 80 & 80 & 0 & 80 & 100 & 100 & 40 & 500 & 62.5 \\
\hline
\end{tabular}

\section{Gambar 8. Halaman Rekapitulasi Nilai}

Dan halaman grafik perkembangan merupakan halaman yang dapat membantu siswa, guru maupun orang tua untuk melihat perkembangan siswa selama proses pembelajaran.

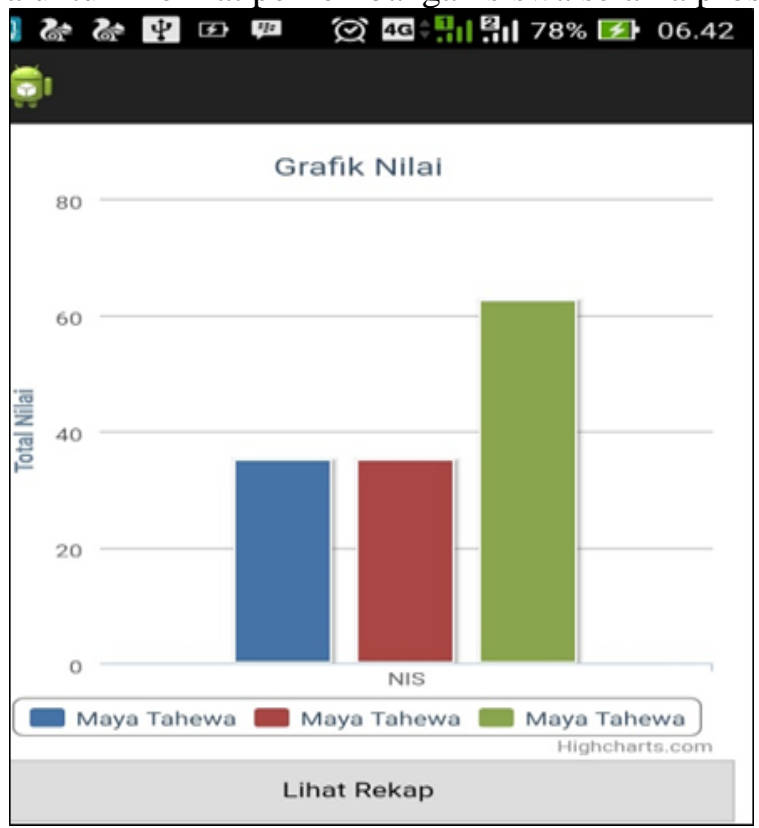

\section{Gambar 9. Halaman Grafik Perkembangan}

\section{KESIMPULAN}

Berdasarkan hasil analisis dan pembahasan sistem pada bab-bab sebelumnya, maka dapat disimpulkan Sistem Informasi Pembelajaran Dasar Anak Retardasi Mental Berbasis Android menghasilkan berupa:

1. Aplikasi pembelajaran ini dibangun sebagai media alternatif dalam pembelajaran untuk anak retardasi mental setingkat SDLB C. Sistem pembelajaran ini berbasis android, sehingga anak retardasi mental dapat belajar dan menjawab latihan dimana saja dan kapan saja melalui smartphone dengan tampilan kolaborasi teks, gambar, dan suara.

2. Aplikasi ini menghasilkan laporan nilai siswa, dan peringkat berdasarkan hasil nilai yang didapat oleh siswa serta menampilkan output perkembangan belajar siswa berdasarkan nilai dalam bentuk grafik.

\section{DAFTAR RUJUKAN}

Dennis, A., Wixom, B. H., \& Roth, R. M. (2012). System Analysis and Design Fifth Edition. New Jersey: John Wiley and Son, Inc. 
80 | JUSIFO (Jurnal Sistem Informasi), p-ISSN: 2460-092X, e-ISSN: 2623-1662

Irwansyah, E., \& Moniaga, J. v. (2014). Pengantar Teknologi Informasi. Yogyakarta: Deepublish.

Ladjamudin, A.-B. B. (2013). Analisis dan Desain Sistem Informasi. Yogyakarta: Graha Ilmu. Nugroho, E. (2010). Sistem Informasi Manajemen Konsep, Aplikasi, dan Perkembangannya. Yogyakarta: Andi Offset.

Pressman, R. (2012). Rekayasa Perangkat Lunak (Pendekatan Praktisi) Edisi 7. Yogyakarta: Andi.

Soetjiningsih. (2009). Tumbuh Kembang Anak. Jakarta: Kedokteran ECG. 